\title{
What Kind of Leadership Fosters Pedagogically Innovative School Culture?
}

\section{Vaara, Lauri}

2014-11

Vaara , L \& Lonka , K 2014 , ' What Kind of Leadership Fosters Pedagogically Innovative School Culture?' ' The European Journal of Social \& Behavioural Sciences, vol. 11 , no. 4 , pp. 1626-1637 . https://doi.org/10.15405/ejsbs.145

http://hdl.handle.net/10138/232972

https://doi.org/10.15405/ejsbs.145

cc_by_nc_nd

publishedVersion

Downloaded from Helda, University of Helsinki institutional repository.

This is an electronic reprint of the original article.

This reprint may differ from the original in pagination and typographic detail.

Please cite the original version. 


\title{
The European Journal of Social and Behavioural Sciences EJSBS
}

(eISSN: 2301-2218)

\section{What Kind Of Leadership Fosters Pedagogically Innovative School Culture?}

\author{
Lauri Vaara ${ }^{\mathrm{a}}$, Kirsti Lonka ${ }^{\mathrm{b}}$ \\ Corresponding Author: Lauri Vaara \\ ${ }^{a}$ Lauri Vaara, P.O. Box 9, 00014, University of Helsinki, Finland, +358440772373 \\ ${ }^{b}$ Kirsti Lonka, P.O. Box 9, 00014, University of Helsinki, Finland, +358503182181 \\ http://dx.doi.org/10.15405/ejsbs.145
}

\begin{abstract}
The implementation of new engaging learning environments also calls for an innovative organizational culture. Still, there is not much knowledge about the leadership practices that foster such culture. The aim of this study was to investigate, what kinds of leadership practices can be detected behind innovative school culture and how such practices are related to the ways of teaching and learning. As a result, a wide variety of new leadership practices in innovative school context were revealed. Particularly practices of shared leadership were present, but also elements of strategic leadership could be identified. Interestingly, the interactive leadership practices seemed to foster new kinds of collaborative knowledge practices in different levels of school activity, for example, varying forms of team work and co-operation. The results indicated that an innovative school culture consists of communal and collaborative practices which are guided by practices of shared leadership. It is important that we take in account the surrounding organization culture when designing future schools. We should also be aware of the possible contradiction between the existing organizational culture and intended new pedagogical settings by arranging a comprehensive and collaborative design process.
\end{abstract}

C 2014 Published by Future Academy www.FutureAcademy.org.uk

Keywords: organizational culture; leadership; learning environment; school

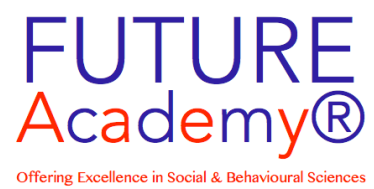

Open Access licence: (c) $\Theta \Theta$ (i) $\Theta$ http://creativecommons.org/licenses/by-nc-nd/4.0/

http://dx.doi.org/ 


\section{Introduction}

Current theories see learning as an active, constructive process rather than a passive, reproductive process (Bruner, 1996; Lonka, Joram \& Bryson, 1996). While such socio- constructivist approach to learning and knowledge has become dominant in educational research, the current pedagogical practices in Finnish schools still very much rely on teacher-centered methods. Classroom learning and teacher education appear to change quite slowly. There are attempts, for instance, to change the practices of teacher education towards inquiry-based and student-centered forms of learning (Litmanen et al., 2012; Lipponen \& Kumpulainen, 2011; Lonka, 2012), but such changes still appear to be more of exceptions than the rule. There are also plenty of innovative schools and projects that aim at bringing schools into the $21^{\text {st }}$ century. (Smeds et al, 2011; http://innoschool.tkk.fi, http://omnischool.fi/, wiredminds.fi)

Official guidelines by the Finnish National Board of education call for innovative inquiry-based collaborative methods that makes students participate in developing $21^{\text {st }}$ century skills: solving problems, posing explanations, and developing their conceptions through collaborative inquiry (Loyens \& Gijbels, 2008; Muukkonen, 2011). This process is driven by the urge to pose questions and to seek explanations, aiming at working toward understanding (Bereiter \& Scardamalia, 2003; Hakkarainen, 2009; Lonka, Hakkarainen \& Sintonen, 2000). The new technology-mediated blended learning environments allow extending these inquiry practices across a wide variety of learning environments (Osguthorpe \& Graham, 2003; Graham, 2006). Not enough innovative effort, however, has been put to integrate architectural and pedagogical design with the new technological tools.

In Finland, student activating and inquiry-based methods have become increasingly popular during the last two decades (Hakkarainen, Lonka \& Lipponen, 2004; Lonka \& Ahola, 1995; Kumpulainen et al, 2010; Muukkonen, 2011). The burning question during the last few years has been, however, is it really necessary to carry out major changes in education: the Finnish education system is already well-known for its quality and equality (Sahlberg, 2011). The common question usually follows: why fix something that isn't broken? Especially the top results in the international PISA-test (OECD, 2003; 2006; 2009) has granted Finland a solid position among the countries which are widely considered as the most advanced in the field of education. In a situation like this, the need for new kinds of learning methods and learning environments is difficult to explain for decision makers that have somewhat lulled into the current quite good and familiar circumstances.

Recently, however, some critical concerns have expressed concerning the current conventions in Finnish education. First, Finland's position in the PISA-ranking sank notably in the latest measurement (OECD, 2013). Then, disquieting results rose also from a nationwide evaluation research executed by the Centre for Educational Assessment of the University of Helsinki: the results revealed that the learning results and positive attitude toward schoolwork of ninth graders in Finland had deteriorated explicitly between the years 2001 - 2012 (Hautamäki et al, 2013). Because these results of both international and national evaluation were published almost at the same time, it led to a wide public debate about the state and future of Finnish education. As usual, the discussion was twosided: some blamed the traditional teacher-centred approach for too much on one-way knowledge transmission and therefore alienating the students, while some others saw the increasing use of ICT and student-activating learning methods as a threat. Furthermore, one of the most controversial questions was, and actually still is, whether pupils should enjoy school. 
As a result many fear, that the reputation of Finnish school system is now at stake. This concern has made room for alternative approaches to learning and teaching. In this quite peculiar situation, some recent research results can, however, be seen as hints to figure out the right direction. It is a fact, for instance, that school exhaustion (Salmela-Aro \& Tynkkynen, 2012) and school-related cynicism and inadequacy has increased among students on an academic track (Salmela-Aro et al, 2008). Furthermore, in the latest measurement by OECD (2013) the students' school engagement in Finland fell exceedingly beneath the OECD average. In addition to these alarming findings, there are also other elements of change that have entered the field of Finnish school system: the emphasis of $21^{\text {st }}$ century skills in education (Binkley et al, 2012) and the introduction of the rapidly developing information technology in education. The generation of the so called digital natives (Prensky, 2006) appears to adopt the new skills and technologies more effectively than the majority of their teachers. Prensky (2006) pointed out that there is a discontinuity between the digital natives, who have been using socio-digital technologies from very early on as compared to their teachers and parents, who learned to use such devices during their adulthood. This development has created an obvious gap between the knowledge practices of students and teachers (Hakkarainen, 2009: www.wiredminds.fi).

\section{Problem Statement}

These somewhat confusing and unpredictable directions of development form the major challenge for contemporary schools in Finland: how to deal with the changes, transform them into elements of quality education and still maintain a positive working atmosphere for both the teachers and their students. The emphasis in the general discussion lies in pedagogy, which of course is reasonable in the context of education, but how can we expect to execute crucial pedagogical changes without developing a corresponding and thus supportive organizational culture? Eventually, a school is just one of the institutions that try to survive and succeed in our unpredictable and rapidly changing environment. Furthermore, the educational system should be able to prepare the next generation for future demands (OECD, 2013). The majority of businesses and companies have already taken into consideration the global trends and challenges by adapting innovation and collaboration driven practices to respond more quickly and flexible to the markets' current demands. Interestingly, this development has brought many companies closer to the field of education: complex learning, pedagogical expertise and knowledge management are valuated high (Senge, 1990; Nonaka et al, 2000; Lick, 2006). This progression has led to several new collaborative and learning centred approaches like learning teams (Lick, 2006), team leadership (Senge, 1990), shared leadership (Wang et al, 2014) and networked expertise (Hakkarainen, 2004; 2009). Naturally, it would be reasonable to expect somewhat similar development in school context. Nevertheless, there is not much research that approaches school as a comprehensive organizational culture and explores the potential of the inner dynamics in the context of an ever changing and unpredictable reality.

However, we already know something about innovative schools. For instance, the model of innovative and progressive school by Ilomäki and Lakkala (2011) displays well the need for a multilevel approach in developing innovative schools by dividing the school culture into six significant areas: 1. grate of ambition, 2. leadership, 3. knowledge practices, 4. role of ICT, 5 . working practices of the teacher community, and 6. pedagogical practices. This kind of approaches could indicate, that schools' organizational structures are expanding and there is a need to examine the schools' activities from a more comprehensive and company like point of view. Furthermore, a larger scale approach in school design and development could also respond to the major challenges in school reality, especially from the perspective of leadership. For instance, according to a survey made in Finland by Karikoski (2009) the principles spend only $8 \%$ of their working time in pedagogical development work, mainly because of the swelled administrative responsibilities. Karikoski (2009) states, that decentralization of leadership, network, constant interaction and mastery of emotional 
skills are in key position when it comes to balance school leadership and inner social cohesion. Progress like that will eventually lead to a more flat, team and networked-based organization where the basic mode of operations is usually based on boundary crossing (e.g. Lipnack \& Stamps, 1993). The idea behind boundary crossing is quite simple and long known: redeem the potential embedded in transporting ideas, concepts and instruments from seemingly different domains in to the domain of focal inquiry (e..g. Bartlett, 1958; Margolis, 1993). Still, the enforcement of such approach can be quite demanding (Engeström, 1995).

However, as mentioned earlier, there is strong need to bring boundary crossing like and inquiry based approach into education, but little is known about the practices that enables the execution of such approach at a concrete level. Furthermore, what is eventually the difference between pedagogical practices and leadership practices in a reality, where learning is widely considered to be a key element of leadership? For instance Nonaka et al (2000) states out that, an enterprise shouldn't be an information processing machine but an entirety, which creates new information through action and collaboration. Moreover, Nonaka \& Konno (1998) call this platform of collaborative knowledge building $B a$, which is according to them a physical, virtual or mental place, where individuals are able to exploit all the collective information while building new knowledge in collaboration with others. Hence, joining the $B a$ enables the individuals to stretch the limits of their own knowledge (Nonaka \& Konno, 1998). This adheres also to Vygotsky's (e.g. 1978) idea of zone of proximal development, which refers to the distance between the learner's ability to perform a task under guidance or peer collaboration and the learner's ability solving the problem independently.

In this study the aim is to close up the pedagogical and organizational dimensions by examining the relation of those dimension from a socio-constructive approach and by adding to the examination concepts of leadership that are in line with the socio-constructive approach. The emphasis of this study lies in the varied practices of an innovative school culture. According to Schatzkin (2001) the origin of practices lies in individual or collective selection of activities that includes attitudes, beliefs and tacit knowledge. Those practices are applied into reality through material or conceptual artefacts (Schatzkin, 2001). However, there are different kinds of practices. For instance, social practices defines the nature of social interaction (Schatzkin, 1996), while knowledge practices are used for obtaining and managing information (Hakkarainen, 2009). In addition, the introduction of contemporary ICT applications has brought almost infinite possibilities to create new tool to support especially knowledge practices (Hakkarainen, 2009). However, we still don't know exactly how schools are developing and utilizing practices for different purposes.

\section{Research Questions}

The premise of this research formed the practical challenges in design of new learning environment and this study is part of a larger nationwide research programme that focuses on a comprehensive design of future indoor environments (RYM SHOK Indoor Environment, http://rym.fi/program/indoor-environment/). The present study shall explore, what kinds of contemporary leadership practices can be found behind innovative school culture and how such practices are related to the ways of teaching and learning in some innovative Finnish schools.

\section{Purpose of the Study}

In order to produce functionality in learning environments, we have to acknowledge the role of organizational culture and leadership already in the construction process. Innovative design calls for innovative leadership. This principle guided our study, leading us to investigate the practices of 
innovative school culture in a real life context. This study underlines the important role of the school's organizational culture when it comes to shifting the school's pedagogical emphasis and building new learning environments to support them. Successful changes require the support and justification of the surrounding culture. Although the context of the study is Finland, the study's quite general results can be utilized in many countries with a similar situation in education as in Finland. Furthermore, the overall aim of this research is to form a comprehensive understanding about the vital sections of contemporary school activity for designing future learning environments.

\section{Research Methods}

The data were gathered by interviewing nine principles or teachers who were in different leading positions from primary to high school. The chosen schools were generally known as future-oriented educational institutes, whose staff had been engaged in varying development projects, for instance InnoSchool (Smeds et al, 2011; http://innoschool.tkk.fi) and the national Dream School Project (http://dreamschool.eu/). The schools were located in metropolitan area of Helsinki, Finland. The participants had been involved in various development processes or had other experience or insight about developing school culture and leadership. They were suggested by the schools' principals, when asked about innovative teachers

The methodological approach a qualitative case study method (Stake, 1995; Creswell, 2009). The cases consisted of three schools that were generally known for their innovative and progressive practices. Semi-structured interview (Hillary \& Knight, 2009) were then analyzed by using qualitative content analysis (Patton, 1990; Tuomi \& Sarajärvi, 2002), abductive strategy (Coffey \& Atkinson, 1996; Paavola et al, 2006; Morgan, 2007)) and phenomenological approach (Willis, 2007; Laine, 2010).

\section{Findings}

The results of this study indicate that the organizational culture of an innovative school consists of various social practices that fosters collaborative knowledge creation and shared leadership. Interestingly, the majority of the practices seem to occur at an interface between the traditional domains of classroom activities and formal administration. This led to a classification where the school's activities are categorized in three zones: zone of classroom activities, zone of communal activities and zone of administrative activities (see table1).

The zone of communal activities includes many social practices that fosters boundary crossing (Engeström, 1995) between different grades and subjects. For instance the practice class grade teams enables a forum for different subjects at the same grade and pedagogical cafes gathers together employees from all over the school community. From the perspective of networked expertise (Hakkarainen et al, 2004) the configuration at the interface level is promising, although veritable technology-mediated knowledge practices (e.g. Hakkarainen, 2009) could not be identified. However, practices like remit teams, where experts from various school related domain work together to cover a certain area of responsibility, can be seen as a potential platform for networked expertise.

Another interesting finding of this study are the different functions of practices. Some practices were very concrete, while some were quite general and suggestive. Furthermore, there were supportive practices that were developed just to enable the execution of other practices. This finding could indicate that there is a need for different kind of practices: the general practices 
suggest to carry out certain kind of activities, for instance communal knowledge practices. Then the community needs a selection of concrete practices to apply the general practices, like internal teacher training. However, to enable the teachers' participation also supportive practices are needed, for instance principle's classes.

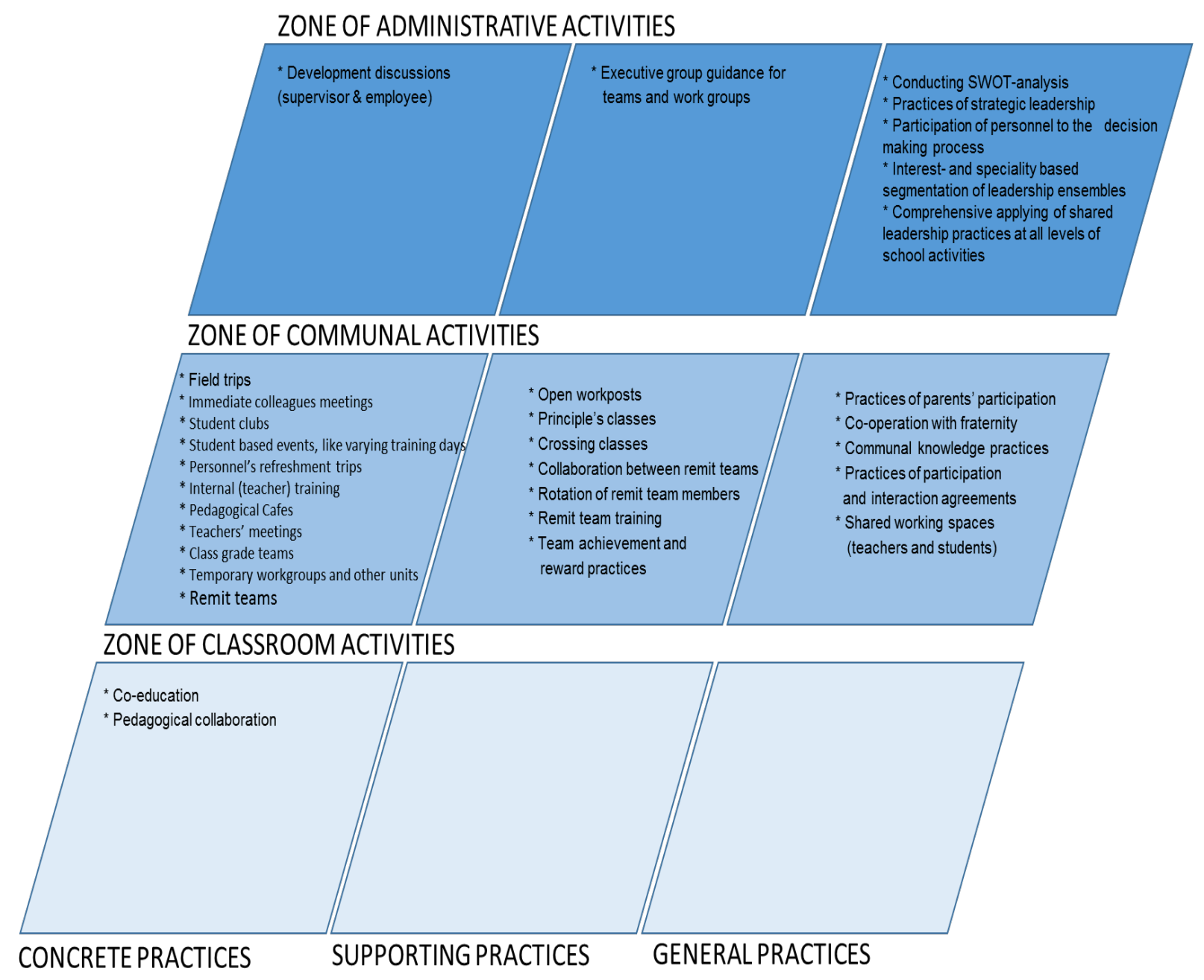

Table 1: Zones of school activities and types of practises

\subsection{Various practices - examples of analysis}

The activities that the teachers described varied notably in specificity. Some practices were very concreate and detailed while others were more principled and general. The difference appears explicitly in the following two practices:

Temporary workgroups 
We have this party and therefore we have arranged a workgroup with a person in charge, who's responsible for the workgroup's actions. (T4)

Interaction agreements

And we need those interaction agreements, so that we all know how we're working here and under which rules, so we wrote these interaction rules, and there is for example this one very important rule, that don't shoot another's enthusiasm down.(T2)

Like described above, the schools had developed various practices to enable their contemporary key practices. The functionality of the remit teams for instance were ensured by more than one supporting practices. Below described four of them. The last one is an example on how teachers' participation in remit teams is enabled during a usual workday.

Rotation of team members

If the chemistry isn't working (in a team) then the team isn't workin either. And then the principle has to be very wise, because he can do the decision to change team members. And he has to know who could balance the team or bring some more energy. (T9)

Collaboration between teams

I just thought that because the sense of belonging is based quite much on the teams and the teams are working pretty much on their own. So we have these practices to bring teams together so the feeling of community could also be formed on a larges scale (between teams). (T9)

Team reward and achievement system

And there is this small thing, that has supported this (team) action, and that is the team reward that the team can share between the team members. And this makes possible that not everyone has to participate as much as the others and no one blames the one isn't doing as much as the others. However, we have all different circumstances in life and I think that this reward system is a very cruzial thing behind this (team work). (T5)

Crossing classes (Teachers freed from study for few hours with the help of substitutes).

For the teachers we have reserved 1-2 team planning days, when the subtitutes do the work. In matter of fact, we watch a video and then discuss about it. And in the time being, the teachers might have a training or something elsewhere. (T2)

\subsection{Remarks on the results}

Table 1 shows that only few pedagogical practices could be found. This is mainly because this study focused in activities of leadership and organizational culture. If the emphasis of the interview would have been more classroom centered, perhaps more pedagogical practices were identified. However, also question about inquiry-based and student-activating learning methods were asked. In this case the results could indicate, that the schools had thought of general practices to support student-activating learning results, but the concrete practices were still under consideration.

The multilevel nature of many practices formed quite a challenge for a strict categorization. For instance the practice of principle's classes can be seen also as pedagogical practice. 
Principal's classes

..so I free all the teachers of a specific grade from teaching for two ours and take all their pupils to me and discuss with them about various important issues from the perspective of a principals, like bullying and making inventions and we talk about friendship and things like that. ( T2)

Nevertheless, the main reason for the school to have developed a practice like that was to free the teachers for a while from their teaching responsibilities to enable their participation in different team related work, and that's why it is labeled as a supporting practice. Also the most of the general practices can be utilized in all of the zones of activities. For instance practices of participation and interaction agreements can be used almost on every occasion.

In contrast to the traditional arrangement, where different activities are put into practice in a classroom or at the administrative level, the employee in an innovative school seems to operate surprisingly much at an interface where the pedagogical everyday challenges encounters the guidance and ambitions of the administrative level. This could also be seen as knotworking between administration and pedagogical practices or as a platform for reflection and building mutual trust. Furthermore, the teachers thought that those interface activities really helped them in their work by providing collegial aid and guidance.

From the perspective of leadership, the results reveal something that can be described as a communal extension of leadership. This extension on the interface between classroom reality and administrative level enables a platform for collaborative knowledge building, professional development and the applying of new emphasizes from the school's strategy or other official guidelines. Furthermore, it gives the head of the school a natural possibility to participate and commit the employees to the organizations vision and aim. This definition is somewhat similar to the concept of $B a$ (Nonaka \& Konno, 1997) and therefore the zone of communal activities could be considered as a starting point for creating a $B a$ like environment for collaborative knowledge creation and learning.

\section{Conclusions}

In this article I have observed the nature of an innovative and progressive school's community from the view of leadership and organization culture by introducing several practices which describes how the community works and on which emphasis. The results shows that there is a strong need to take into consideration the multilevel structure of an innovative school culture when designing new innovative learning environments. According to the results, innovative schools have developed various supporting practices between the official administration and classroom teaching to provide a zone of communal activities for binding together the pedagogical and administrative aspects of a school culture. Furthermore, this level can be used by the leaders to stretch the eligible pedagogical philosophy from vision to practice and to form a more consistent and involved school culture. It also can provide natural possibilities for sharing liabilities and expertise in the manner of shared leadership. For teacher the practices in this level enable a possibility for professional development and collective support. We can see the collective level of actions as a flexible extension of both classroom teaching and official administration. A channel for information stream and an environment for collaborative knowledge building. 
Nevertheless, the reality seems to be quite obscure: some schools have developed remarkable new practices when it comes to collaboration, knowledge management and leadership, while some are still sticking with more inflexible and hierarchical conventions at the organizational level. However, updating the practices of the organizational culture in a way that they fit better to the current needs should be a collective concern. The key to this update is leadership: how we see it and how we put it into practise. This is why it is very reasonable to observe not only the relation between teaching and learning but also between teaching and leading. Furthermore, in an innovative school the practices of teaching and learning should be in line with the organizations leadership philosophy and vice versa. How reasonable is it to assume that pedagogical updates can be made without a congruent progression at the level of leadership? Regardless, this study strongly indicates that innovative design calls for innovative leadership. Furthermore, the critical question is, how to create an innovative and collaborative organizational culture and learning environment in a school to support a visionary and flexible pedagogical grasp. A grasp that could also be called future sensitive education, which I will focus on my following research.

\section{References}

Bereiter, C., \& Scardamalia, M. (2003). Learning to work creatively with knowledge. In E. De Corte, L. Verschaffel, N. Entwistle, \& J. van Merriënboer (Eds.), Powerful learning environments: Unraveling basic components and dimensions (pp. 55-68). (Advances in Learning and Instruction Series). Oxford, UK: Elsevier Science.

Bartlett, F. (1958) Thinking: An experimental and social study. London: Allen \& Unwin.

Binkley, M., Erstad, O., Herman, J., Raizen, S., Ripley, M., Miller-Ricci, M., \& Rumble, M. (2012). Defining Twenty-First Century Skills. Teoksessa P. Griffin, B. McGaw, \& E. Care (toim.), Assessment and Teaching of $21^{\text {st }}$ Century Skills (s.17-66). New York: Springer Publishing.

Bruner, J. (1996). The culture of education. Cambridge, MA: Harvard University Press.

Coffey, A., \& Atkinson, P. (1996). Making sense of qualitative data. Complementary research strategies. Thousand Oaks, CA: Sage.

Creswell, John (2009). Research Design; Qualitative and Quantitative and Mixed Methods Approaches. London: Sage

Engeström, Y., Engeström, R., \& Kärkkäinen, M. (1995). Polycontextuality and boundary crossing in expert cognition: learning and problem solving in complex work activities. Learning and Instruction, 5, 319-336.

Graham, C. R. (2006). Blended learning systems: Definitions, current trends and future directions. Teoksessa J. Bonk, \& C. R. Graham (toim.), The Handbook of Blended Learning (s. 3-21). San Francisco: Pfeiffer.

Hakkarainen, K., Lonka, K., \& Lipponen, L. (2004a). Tutkiva oppiminen. Järki, tunteet ja kulttuuri oppimisen sytyttäjänä. Helsinki: WSOY.

Hakkarainen, K., Palonen, T., Paavola, S., \& Lehtinen, E. (2004b). Communities of networked expertise. Professional and educational perspectives. Helsinki: Sitra.

Hakkarainen, K. (2009). A knowledge-practise perspective on technology-mediated learning. Computer-Supported Collaborative Learning, 4(2), 213-231. 
Hautamäki, J., Kupiainen, S., Marjanen, J., Vainikainen, M-P. \& Hotulainen, R. (2013). Oppimaan oppiminen peruskoulun päättövaiheessa. Tilanne vuonna 2012 ja muutos vuodesta 2001Tutkimuksia 347. Helsingin yliopiston opettajankoulutuslaitos ja Koulutuksen arviointikeskus. Helsinki: Yliopistopaino.

Hillary, A., Knight, P. (1999). Interviewing for social scientists. Thousand Oaks, Calif: Sage.

Ilomäki, L., \& Lakkala, M. (2011). Koulu, digitaalinen teknologia ja toimivat käytännöt. Teoksessa M. Kankaanranta \& S. Vahtivuori-Hänninen (toim.), Opetusteknologia koulun arjessa II (s.55-76). Jyväskylä: Jyväskylän yliopistopaino.

Karikoski, A. (2009). Aika hyvä rehtoriksi. Selviääkö koulun johtamisesta hengissä. Helsinki: Yliopistopaino.

Kumpulainen, K., Krokfors, L., Lipponen, L., Tissari, V., Hilppö, J., \& Rajala, A. (2010). Learning bridges - towards participatory learning environments. Helsinki: Helsinki University Print.

Laine, T. (2010). Miten kokemusta voidaan tutkia? Fenomenologinen näkökulma. Teoksessa J. Aaltola \& R. Valli (toim.), Ikkunoita tutkimusmetodeihin II (s. 28-45). Jyväskylä: PSkustannus.

Lick, D. (2005). A new perspective on organizational learning: creating learning teams. Evaluation and Program Planning, 29(2006), 88-96.

Lipnack, J., Stamps, J. (1993). The teamnet factor: bringing the power of boundary crossing into the heart of your business. Essex Juction: Oliver Wight.

Lipponen, L., \& Kumpulainen, K. (2011). Acting as accountable authors: Creating interactional spaces for agency work in teacher education. Teaching \& Teacher Education, 27(5), 812819.

Litmanen, T., Lonka, K., Inkinen, M., Lipponen, L., \& Hakkarainen, K. (2012). Capturing teacher students' emotional experiences in context: Does inquiry-based learning make a difference? Instructional Science: An International Journal of the Learning Sciences, 2012, Vol.40(6), s.1083-1101.

Lonka, K., \& Ahola, K. (1995). Activating instruction: How to foster study and thinking skills in higher education? European Journal of Psychology of Education, 10(4), 351-368.

Lonka, K., Hakkarainen, K., \& Sintonen, M. (2000). Progressive inquiry learning for children-experiences, possibilities, limitations. European Early Childhood Education Research Journal, 8(1), 7-23.

Lonka, K., Joram, E. \& Bryson, M. (1996) Conceptions of learning and knowledge - does training make a difference? Contemporary Educational Psychology, 21(3), 240-260.

Lonka, K. (2012). Engaging Learning Environments for the Future - The 2012 Elizabeth W.Stone Lecture. Teoksessa R. Gwyer, R. Stubbings \& G. Walton (toim.), The Road to Information Literacy (s. 15-29). Berlin/Munich: De Gruyter Saur.

Loyens, S. M. M., \& Gijbels, D. (2008). Understanding the effects of constructivist learning environments: Introducing a multi-directional approach. Instructional Science, 36(5), 351357.

Margolis, H. (1993). Paradigms and barriers: how to habit of mind govern scientific beliefs. Chicago: University of Chicago Press. 
Morgan, D. (2007). Paradigms lost and pragmatism regained: Methodological implications of combining qualitative and quantitative methods. Journal of Mixed Methods Research, 1(1), $48-76$.

Muukkonen- van der Meer, H. (2011). Perspective on knowledge creating inquiry in higher education. Doctoral dissertation. Institute of Behavioural Sciences. University of Helsinki, Finland. http://www.e-thesis.helsinki.fi

Nonaka, I., \& Konno, N. (1998). The concept of "Ba": Building a foundation for knowledge creation. California Management Review, 43(3), 40-54.

Nonaka, I., Toyama, R. and Konno, N. (2000). 'SECI, Ba, and leadership: a unified model of dynamic knowledge creation'. Long Range Planning, 33, pp 5-34.

OECD (2013). OECD Skills Outlook 2013: First Results from the Survey of Adult Skills. OECD Publishing. http://skills.oecd.org/OECD_Skills_Outlook_2013.pdf

Osguthorpe, R. T. \& Graham, C. R. (2003). Blended learning environments: definitions and directions. Quarterly Review of Distance Education, 4(3), 227-233.

Paavola, S., Hakkarainen, K., \& Sintonen, M. (2006). Abduction with dialogical and trialogical means. Logic Journal of the IGPL 14(2), 137-150.

Patton, M. (1990). Qualitative research and evaluation methods. Newbury Park, CA: Sage Publications.

Prensky, M. (2006). Don't Bother Me, Mom - I'm Learning!. St. Paul, MN: Paragon House.

Sahlberg, P. (2011) Finnish Lessons: what can the world learn from educational change in Finland? New York: Teachers College Press.

Salmela-Aro, K., Kiuru, N., Nurmi, J-E. (2008). The role of educational track in adolescents' school burnout: A longitudinal study. British Journal of Educational Psychology, 78(4), 663-689.

Salmela-Aro, K. \& Tynkkynen, L. (2012).Gendered Pathways in School Burnout among Adolescents. Journal of Adolescence, 35 (4), 929-939

Schatzki, T. (1996). Social Practices - A Wittgensteinian Approach to Human Activity and the Social. Cambridge, MA: Cambridge University Press.

Schatzki, T. (2001). Introduction: Practice theory. Teoksessa T. Schatzki, K. Knorr-Cetinas, \& E. von Savigny (toim.), The practice turn in contemporary theory (s. 1-14). London: Routledge.

Senge, P. (1990). The Fifth Discipline: The Art and Practise of the Learning Organization. Michigan, US: The University of Michigan Press.

Smeds, R., Krokfors, L., Ruokamo, H., Staffans, A. (2010). InnoSchool-välittävä koulu. Oppimisen verkostot, ympäristö ja pedagogiikka.Espoo, FIN: Painotalo Casper Oy.

Stake, E. (1995). The Art of Case Study Research. Thousand Oaks: Sage.

Tuomi, J., \& Sarajärvi, A. (2002). Laadullinen tutkimus ja sisällönanalyysi. Helsinki: Tammi.

Wang, D., Waldman, D., Zhang, Z. (2014). A meta-analysis of shared leadership and team effectiveness. Journal of Applied Psychology, 99(2), 181-198.

Willis, J. (2007). Foundations of Qualitative Research: Interpretive and Critical Approaches. ThousandOaks: Sage Publications. 
http://dx.doi.org/

eISSN: 2301-2811 / Corresponding Author: Lauri Vaara

Selection and peer-review under responsibility of the Organizing Committee of the conference

Vygotsky, L. S. (1978). Mind in society: the development of higher psychological processes. Cambridge, MA: Harvard University Press. 